\title{
Gradients of light availability and leaf traits with leaf age and canopy position in 28 Australian shrubs and trees
}

\author{
Ian J. Wright ${ }^{\mathrm{A}, \mathrm{C}}$, Michelle R. Leishman ${ }^{\mathrm{A}}$, Cassia Read ${ }^{\mathrm{A}, \mathrm{B}}$ and Mark Westoby ${ }^{\mathrm{A}}$

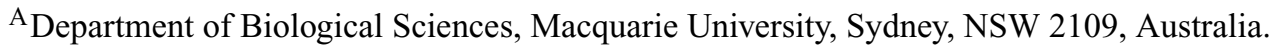 \\ ${ }^{B}$ Current address: School of Botany, The University of Melbourne, Parkville, Vic. 3010, Australia. \\ ${ }^{\mathrm{C}}$ Corresponding author. Email: iwright@rna.bio.mq.edu.au \\ This paper originates from a presentation at ECOFIZZ 2005, North Stradbroke Island, Queensland, \\ Australia, November 2005.
}

\begin{abstract}
Light availability generally decreases vertically downwards through plant canopies. According to optimisation theory, in order to maximise canopy photosynthesis plants should allocate leaf nitrogen per area $\left(\mathrm{N}_{\text {area }}\right)$ in parallel with vertical light gradients, and leaf mass per area (LMA) and leaf angles should decrease down through the canopy also. Many species show trends consistent with these predictions, although these are never as steep as predicted. Most studies of canopy gradients in leaf traits have concerned tall herbaceous vegetation or forest trees. But do evergreen species from open habitats also show these patterns? We quantified gradients of light availability, LMA, leaf $\mathrm{N}$ and phosphorus (P), and leaf angle along leaf age sequences and vertical canopy profiles, across 28 woody species from open habitats in eastern Australia. The observed trends in LMA, $\mathrm{N}_{\text {area }}$ and leaf angle largely conflicted with expectations from canopy optimisation models, whereas trends in leaf $\mathrm{P}$ were more consistent with optimal allocation. These discrepancies most likely relate to these species having rather open canopies with quite shallow light gradients, but also suggest that modelling the co-optimisation of resources other than nitrogen is required for understanding plant canopies.
\end{abstract}

Keywords: canopy structure, leaf angle, nitrogen, optimisation models, phosphorus, photosynthesis.

\section{Introduction}

Because light availability generally decreases vertically downwards through plant canopies, predictions can be made as to how canopies should be organised so that wholeplant photosynthesis would be maximised. Such 'optimality' predictions not only concern the most effective leaf area index (total leaf area per unit ground area, LAI) for a given level of incoming solar radiation (Monsi and Saeki 1953) but also concern vertical variation in leaf traits through the canopy. For example, the following properties have been predicted to decrease vertically in parallel with decreasing light availability: (1) the fraction of the total leaf area held at a given height (Monsi and Saeki 1953; Givnish 1982; Gutschick and Wiegel 1988); (2) leaf erectness, i.e. the angle relative to vertical (Monsi and Saeki 1953; Kuroiwa 1971); (3) leaf nitrogen content per unit leaf area, $\mathrm{N}_{\text {area }}$ (Mooney and Gulmon 1979; Field 1983;
Hirose and Werger 1987; Werger and Hirose 1991); and (4) leaf mass per area (LMA) of individual leaves (Gutschick and Wiegel 1988). Vertical gradients in $\mathrm{N}_{\text {area }}$ can come about through variation in $\mathrm{N}$ content when leaves are first constructed, as well as through resorption and redeployment of $\mathrm{N}$ to better-lit, newly developing leaves. Because the potential photosynthetic benefit resulting from a non-uniform vertical $\mathrm{N}_{\text {area }}$ distribution should increase in concert with the severity of the vertical light gradient (Mooney et al. 1981), the degree of canopy closure and the total amount of canopy $\mathrm{N}$ jointly affect predictions of optimal LAI values and vertical $\mathrm{N}_{\text {area }}$ gradients (Anten et al. 1995, 1998; Schieving and Poorter 1999; Hikosaka 2003). Although observations from many species have broadly supported the predictions from these optimisation models, consistent deviations have been found; observed LAI values are generally higher than predicted, and observed

Abbreviations used: GF, gap fraction; LAI, leaf area index; LL, leaf lifespan; LMA, leaf mass per area; LMI, leaf mass index; $\mathrm{N}_{\text {area }}$, leaf nitrogen content per unit area; $\mathrm{N}_{\text {mass }}$, leaf nitrogen content per unit mass; $\mathrm{P}_{\text {area }}$, leaf $\mathrm{P}$ content per unit area; $\Delta$ absGF, absolute decline in GF; $\Delta$ relGF, relative decline in GF. 
vertical $\mathrm{N}_{\text {area }}$ distributions are more uniform (Anten 2005; Hikosaka 2005; Hirose 2005; Terashima et al. 2005). While the observed $\mathrm{N}_{\text {area }}$ gradients have been calculated to increase canopy photosynthesis by up to $42 \%$ over what would be achieved from uniform $\mathrm{N}_{\text {area }}$ distributions, this has still been from 5 to $14 \%$ less than that predicted to result from optimal distribution patterns (see Anten 2005).

Almost inevitably, as leaves age they occupy successively more poorly lit positions within a plant canopy. Thus, vertical gradients in leaf traits may represent age-related changes in leaf traits as well as, or instead of, plastic responses to a vertical light gradient (Ackerly 1992; Traw and Ackerly 1995; Hikosaka 1996; Anten et al. 1998; Givnish 2002). Age-related decline in photosynthetic capacity has been noted in many evergreen species. Presumably this largely results from decreasing leaf $\mathrm{N}$ content due to resorption (Kitajima et al. 1997; Mediavilla and Escudero 2003b), but continual accumulation and lignification of cell wall materials over time may also contribute through increasing resistance to $\mathrm{CO}_{2}$ diffusion in the mesophyll (Niinemets et al. 2004). The distinction between light-related and age-related shifts in leaf traits is potentially important for understanding plant canopies and for investigating deviations between observations and predictions from canopy optimisation models. We note that, despite the general consistency of these deviations, most studies have considered relatively few species (generally less than five and never more than a dozen), and few studies have considered canopy organisation in woody species from open, high-light habitats (Rambal et al. 1996; Valladares and Pearcy 1999; Valladares and Pugnaire 1999; Werner et al. 2001; Mediavilla and Escudero 2003b; Niinemets et al. 2004). Further, almost nothing is known about canopy organisation in Australian shrubs and trees, with the exception of a small number of commercially important Eucalyptus species (Leuning et al. 1991; Close et al. 2004).

Here we describe two complementary studies in which canopy trends in light availability and leaf traits were quantified for 28 species from open woodland communities in eastern Australia. In the first study, concerning 14 shrub and tree species from semi-arid woodlands $\left(390 \mathrm{~mm}\right.$ year $^{-1}$ rainfall), we measured light attenuation, LMA, leaf angle, leaf $\mathrm{N}$ and phosphorus $(\mathrm{P})$ concentrations and leaf $\mathrm{N}: \mathrm{P}$ ratios in relation to leaf age. In the second study, concerning 14 shrub species from an open woodland at higher rainfall (1220 $\mathrm{mm}$ year $^{-1}$ rainfall), we quantified light attenuation, leaf $\mathrm{N}$ and LMA in relation to leaf age as well as in relation to canopy position. Having confirmed that light availability declined with leaf age and canopy depth we tested whether LMA and $\mathrm{N}_{\text {area }}$ did too, as predicted by canopy optimisation models. It was less clear what to expect with regard to leaf $P$ per area $\left(\mathrm{P}_{\text {area }}\right)$, however leaf $\mathrm{P}$ is of particular interest because $\mathrm{P}$, rather than $\mathrm{N}$, is widely accepted to be the key limiting soil nutrient in many Australian ecosystems (Beadle 1966; Webb 1968). For low rainfall species we also quantified trends in leaf angle along age sequences. Deploying leaves at steep angles in high-light positions can be advantageous through the avoidance of overheating and photoinhibition (Werner et al. 2001; Falster and Westoby 2003). This also increases light penetration to leaves lower down (Kuroiwa 1971); consequently, we predicted that species with this trend in leaf angle would show weaker light attenuation along their leaf age sequences than species with no trend in leaf angle. Finally, we explored relationships between the canopy trends measured in this study and several other leaf and canopy traits measured as part of previous studies: average leaf lifespan (Wright et al. 2002), N and P resorption efficiencies (Wright and Westoby 2003) and, for high rainfall species only, LAI, as well as the total leaf mass per unit ground area (Read et al. 2006).

\section{Materials and methods}

\section{Site and species selection}

At the low rainfall site (Round Hill Nature Reserve; lat / long $32^{\circ} 58^{\prime} \mathrm{S}$, $\left.146^{\circ} 09^{\prime} \mathrm{E}\right)$ species were sampled from two Eucalyptus-dominated subsites: one a mallee community, the other a nearby open woodland. The high rainfall site (Eucalyptus-dominated woodland on sandy, low nutrient soil) was located in Ku-ring-gai Chase National Park $\left(33^{\circ} 41^{\prime} \mathrm{S}\right.$, $\left.151^{\circ} 09^{\prime} \mathrm{E}\right)$. Community-mean LAI was estimated to be $1.7 \mathrm{~m}^{2}$ leaf area per $\mathrm{m}^{2}$ ground area at the high rainfall site and $1.2 \mathrm{~m}^{2} \mathrm{~m}^{-2}$ at both of the two low rainfall subsites (IJ Wright, unpublished data; LAI estimates made with LAI-2000 plant canopy analyser). Species were chosen from among those used in several previous studies (Wright et al. 2001; Wright and Westoby 2002, 2003); note that two distinct subspecies of Dodonaea viscosa were treated as separate entities. Further details about sites and species can be found in those publications.

\section{Low rainfall species: trait shifts with leaf age}

Three individuals were studied for each species (Table 1) except for Eremophila mitchelli (four individuals). Two branch tips that reached the outside surface of the canopy were selected on each plant (chosen randomly with respect to azimuth angle), one near the top of the canopy and one towards the side. The leaf age sequence from the youngest fully expanded leaf to the oldest leaf was identified, moving down $>1$ branch orders where necessary; Fig. 1). Light attenuation was quantified as the change in gap fraction (GF hereafter) from the beginning to the end of each sequence. GF is an estimate of the fraction of sky visible through the canopy and is a good predictor of annual light availability (Comeau et al. 1998; Machado and Reich 1999). GF was measured with a LAI2000 plant canopy analyser (Li-Cor, Lincoln, NE). The fish-eye sensors measure the per cent transmittance of diffuse light at each point, relative to readings taken simultaneously by a second sensor mounted on a tripod in a large adjacent clearing. All measurements were made during periods of continuous cloud cover. Leaf angle was measured with a protractor and plum bob for every leaf in each age sequence. Angles were expressed in three ways: (1) 'midrib' angle, ranging from $0^{\circ}$ (vertical, leaf pointing upwards) to $180^{\circ}$ (vertical, leaf pointing downwards); (2) 'effective' angle: midrib angle recoded so that it ranged from $0^{\circ}$ (vertical) to $90^{\circ}$ (horizontal), i.e. so that a leaf with, say, midrib angle of $20^{\circ}$ from vertical (pointing upwards) was equivalent to one with midrib angle of $160^{\circ}$ from vertical (pointing downwards); (3) 'blade' angle, the steepest angle across the leaf blade (ranging from $0^{\circ}$ vertical to $90^{\circ}$ horizontal), so that any twisting of the petiole would be taken into account. In the absence of twisting blade angle is equivalent to effective midrib angle. Three pooled samples of leaves were collected from each sequence, the mean leaf age differing between each sample: 
Table 1. Summary of trait shifts along leaf age sequences of $\mathbf{1 4}$ species from low rainfall communities in eastern Australia Species codes: AH, Acacia havilandiorum; DVC, Dodonaea viscosa spp. cuneata; DVS, D. viscosa ssp. spatulata; ED, Eremophila deserti; EG, E. glabra; EL, E. longifolia; EM, E. mitchelli; EDu, Eucalyptus dumosa; ES, E. socialis; GP, Geijera parviflora; HT, Hakea tephrosperma; MU, Melaleuca uncinata; PM, Pimelea microcephala; SA, Santalum acuminatum. Trait abbreviations: $\Delta$ absGF, absolute gap fraction decline along leaf age sequences; $\Delta$ relGF, relative GF decline; LMA, leaf mass per area; $\mathrm{N}_{\text {mass }}$ and $\mathrm{P}_{\text {mass }}$, leaf $\mathrm{N}$ and $\mathrm{P}$ concentrations; $\mathrm{N}_{\text {area }}$ and $\mathrm{P}_{\text {area }}$, leaf $\mathrm{N}$ and $\mathrm{P}$ per unit leaf area; Midrib, midrib leaf angle (ranges from $0^{\circ}$ vertical upwards to $180^{\circ}$ vertical downwards); Effective, steepness of midrib (ranges from $0^{\circ}$ vertical to $90^{\circ}$ horizontal); Blade, steepest angle across the leaf blade (ranges from $0^{\circ}$ vertical to $90^{\circ}$ horizontal). Trait shifts were identified with analyses of covariance. absGF and relGF decreased significantly in 13 of 14 species (all $P<0.04$ ), while in PM the decrease was non-significant $(P=0.103)$. The size of the GF shifts from youngest to oldest leaf age classes are given; for other traits the significance level is shown, followed by the sign of the common slope where deemed significant, or marginally so $(0.05<P<0.10)$

\begin{tabular}{|c|c|c|c|c|c|c|c|c|c|c|c|}
\hline Spp. & $\Delta \mathrm{absGF}$ & $\begin{array}{c}\Delta \text { relGF } \\
(\%)\end{array}$ & LMA & $\mathrm{N}_{\text {mass }}$ & $\mathrm{N}_{\text {area }}$ & $P_{\text {mass }}$ & $P_{\text {area }}$ & $\mathrm{N}: \mathrm{P}$ ratio & Midrib & Effective & Blade \\
\hline $\mathrm{AH}$ & 0.11 & 18 & $0.003,+$ & $0.043,-$ & $0.077,+$ & $0.009,-$ & $0.065,-$ & $0.011,+$ & 0.124 & 0.124 & 0.124 \\
\hline DVC & 0.21 & 24 & $0.082,+$ & $0.016,-$ & 0.293 & 0.747 & 0.756 & 0.466 & 0.328 & $0.005,+$ & 0.365 \\
\hline DVS & 0.26 & 28 & $0.020,+$ & $0.001,-$ & $0.007,-$ & $0.002,-$ & $0.005,-$ & 0.531 & 0.878 & $0.055,+$ & 0.395 \\
\hline ED & 0.13 & 27 & $0.010,+$ & $0.035,-$ & $0.077,+$ & $<0.001,-$ & 0.107 & $<0.001,+$ & $0.003,+$ & $0.003,+$ & $0.019,+$ \\
\hline EG & 0.25 & 41 & 0.116 & $0.007,-$ & 0.309 & $<0.001,-$ & $<0.001,-$ & $<0.001,+$ & $<0.001,+$ & $<0.001,+$ & $<0.001,+$ \\
\hline EL & 0.33 & 36 & $<0.001,+$ & $0.019,-$ & $0.007,+$ & $0.014,-$ & 0.363 & 0.556 & $<0.001,+$ & $<0.001,-$ & $0.084,-$ \\
\hline EM & 0.38 & 48 & $0.025,+$ & 0.367 & $0.022,+$ & $<0.001,-$ & $<0.001,-$ & $<0.001,+$ & $<0.001,+$ & $0.002,+$ & 0.423 \\
\hline $\mathrm{EDu}$ & 0.32 & 36 & 0.201 & 0.103 & 0.677 & 0.101 & 0.139 & 0.201 & 0.111 & $0.099,-$ & 0.206 \\
\hline ES & 0.23 & 26 & 0.774 & $0.003,-$ & $0.003,-$ & $0.007,-$ & $0.014,-$ & $0.066,+$ & $0.073,+$ & 0.841 & 0.930 \\
\hline GP & 0.36 & 47 & $<0.001,+$ & $0.002,-$ & 0.130 & $<0.001,-$ & $0.014,-$ & 0.119 & 0.362 & $0.017,-$ & $0.001,-$ \\
\hline HT & 0.40 & 44 & 0.683 & 0.786 & 0.997 & 0.143 & 0.113 & $0.068,+$ & $<0.001,-$ & 0.968 & 0.968 \\
\hline MU & 0.19 & 22 & 0.293 & $0.002,-$ & $0.044,-$ & 0.738 & 0.948 & 0.956 & 0.659 & 0.549 & 0.549 \\
\hline PM & 0.15 & 22 & $0.028,+$ & $0.033,-$ & 0.819 & $0.082,-$ & 0.476 & 0.137 & $0.017,+$ & 0.931 & 0.586 \\
\hline SA & 0.25 & 31 & $0.018,+$ & 0.300 & 0.250 & 0.190 & 0.735 & 0.438 & $0.022,+$ & 0.577 & 0.460 \\
\hline
\end{tabular}

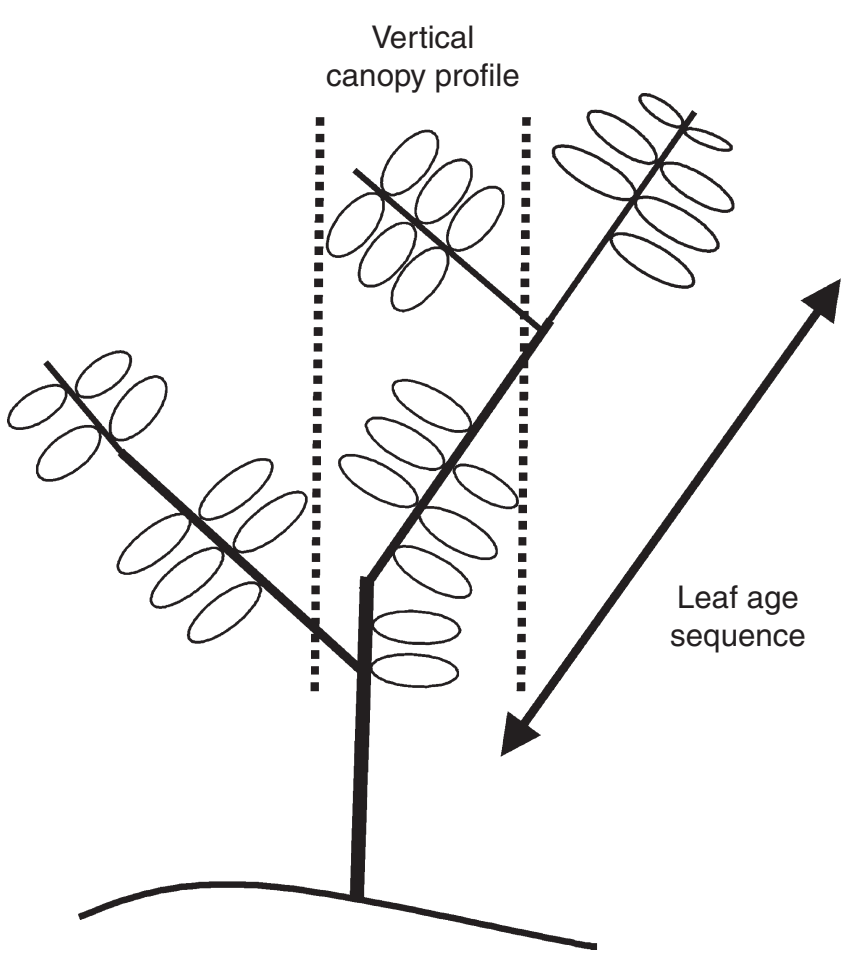

Fig. 1. Schematic of a hypothetical plant showing a leaf age sequence back from the youngest fully expanded leaf. For species sampled at the high rainfall site, this oldest leaf was also used to define the starting point for measuring a vertical canopy profile in light availability and leaf traits. leaf age sequences with $>20$ leaves were divided into five approximately equal-length sections, from which all leaves were collected from the first, third and fifth sections; sequences with $<20$ leaves were divided into three approximately equal-length sections and all leaves collected from each. Average leaf lifespan (LL) of these species ranges from 0.6 to 3.4 years (Wright and Westoby 2002). Consequently, the mean age difference between the first, second and third sample was different from species to species. This was considered appropriate, the main aim being to simply identify whether or not the leaf traits varied with age for each species rather than comparing the exact rates of change. Mean LMA was measured for leaves from each section (leaf area measured on a flatbed scanner, dry mass after drying for $>48 \mathrm{~h}$ at $65^{\circ} \mathrm{C}$ ). Next the leaves were ground and analysed for total $\mathrm{N}$ and $\mathrm{P}$ (Kjeldahl extraction, auto-analyser), except for several lowmass samples from the small-leaved species Pimelea microcephala and Dodonaea viscosa ssp. cuneata, for which total N was measured by mass spectrometry (Europa 20-20 isotope ratio mass spectrometer with a ANCA preparation system, Europa Scientific Ltd). Leaf P could not be measured for these samples. All nutrient analyses were performed at CSIRO Plant Industry, Canberra.

\section{High rainfall species: trait shifts with leaf age and canopy position}

All 14 species were sampled within a 2-ha area. Where possible five individuals per species were studied, chosen randomly from among plants that were $<3.5 \mathrm{~m}$ tall (to enable access to canopies) and reproductively mature, but not obviously moribund or suffering very high levels of herbivory. Only three individuals could be sampled for Hakea dactyloides and four individuals for Gompholobium grandiflorum. Light extinction and leaf traits were measured vertically down through the canopy as well as along leaf age sequences on each plant. One leaf age sequence was identified per plant, chosen as for low rainfall species, and GF measured at several points along the sequence (LAI-2000, Li-Cor). Measurements were generally made 
every $10 \mathrm{~cm}$, but for sequences $>60 \mathrm{~cm}$ long the measurements were made every $20 \mathrm{~cm}$ instead, and for sequences $<30 \mathrm{~cm}$ long just two or three equally-spaced measurements were made (average number of GF measurements per sequence: 4.5 , maximum 10). Each age sequence was then divided into three or four approximately equal-length sections (longer sequences being divided into four), and the leaves from each section were collected and pooled for determination of leaf $\mathrm{N}$ per mass $\left(\mathrm{N}_{\text {mass }}\right)$. The oldest leaf in each leaf age sequence was used as the starting point for profiling canopy properties vertically upwards from this point (Fig. 1). A cylindrical sample volume was defined from the oldest age-sequence leaf to the top of the plant's canopy. The radius of the sample volume was usually $15 \mathrm{~cm}$, but was adjusted between 5 and $20 \mathrm{~cm}$ as necessary depending on leaf size and texture of the canopy to ensure the sample cylinder was wide enough to include large leaves and to avoid passing straight through a canopy gap, but small enough to avoid extending outside the canopy outline (Read et al. 2006). Dimensions of the sample volume were measured with two rulers and a spirit level. Each sample volume was divided into several horizontal slices, each of equal depth. Slice depth was $20 \mathrm{~cm}$ for sample volumes $>60 \mathrm{~cm}$ in depth (approximately $45 \%$ of cases) and $10 \mathrm{~cm}$ for those $30-60 \mathrm{~cm}$ deep (approximately $40 \%$ ); sample volumes $<30 \mathrm{~cm}$ deep were simply divided into three slices. GF was measured at the top of the canopy and then at the bottom of each horizontal slice along the central axis of the sample cylinder. The leaves from each slice were collected separately so that a pooled LMA value could be calculated for each. $\mathrm{N}_{\text {mass }}$ (Kjeldahl; CSIRO Plant Industry, Canberra) was determined for leaves from the top, middle and bottom slices of the sample volume for the majority of plants, and for four slices (top, bottom and two others equally spaced between) for those with deeper vertical profiles (approximately one quarter of plants). $\mathrm{N}_{\text {area }}$ was calculated for each slice as the product of $\mathrm{N}_{\text {mass }}$ and LMA.

\section{Identification of trait shifts along leaf age sequences} and vertical canopy profiles

Analysis of covariance (ANCOVA) was used to determine the extent to which light availability and leaf traits varied with leaf age or canopy depth within each species. The small number of sample points along each age sequence or vertical profile meant that there was little power to detect non-linear trends; consequently, a linear model was used. In each analysis the independent variable (main effect) was either leaf number from branch tip (for leaf angle), position along the age sequence (ordinal; for GF and other leaf traits, low rainfall species) or distance from the branch tip down age sequences or from the top of the vertical canopy profiles (high rainfall species). Individual age sequences or canopy profiles were the replicates (fixed factors) and the dependent variable was either GF, LMA, $\mathrm{N}_{\text {mass }}, \mathrm{N}_{\text {area }}$, $\mathrm{P}_{\text {mass }}, \mathrm{P}_{\text {area }}$, leaf N : $\mathrm{P}$ ratio or leaf angle (midrib, effective and blade angles). The significance level of the main effect indicated whether a common relationship slope could be fitted for a given species (i.e. whether there was any general trend with leaf age or canopy position), the sign of the slope estimate indicating the direction of the trend. Marginally significant results were reported as such $(0.05<P<0.10)$ but included when describing the number of species showing trends in a given trait.

For descriptive purposes the mean size of within-canopy shifts in light availability and leaf traits were also quantified for each species. GF decline from the beginning to the end of age sequences and vertical profiles was expressed both as relative decline (' $\Delta$ relGF', i.e. $\%$ decline) and as absolute decline (' $\Delta$ absGF', i.e. arithmetic difference). Leaf angle trends were described by the average changes in midrib, effective and blade angles along three-quarters of an 'average' leaf sequence for each species, the average change in angle per leaf being given by the common ANCOVA slope, and the average sequence length being the mean number of leaves per sequence for that species. Mean shifts in other leaf traits were described as the percentage difference in trait means between the youngest and oldest leaf age classes, or between the highest and lowest horizontal slices from the vertical sample volumes.

\section{Additional leaf and canopy traits}

Several other traits of interest were known from previous studies made at the sites: average leaf lifespan (Wright et al. 2002), percentage $\mathrm{N}$ and P resorption (Wright and Westoby 2003) and, from the vertical canopy profiles (high rainfall species only), the total leaf area per unit ground area (LAI) and total leaf dry mass per unit ground area (leaf mass index, LMI) (Read et al. 2006). Proportional $\mathrm{N}$ and $\mathrm{P}$ resorption (resorption 'efficiency') was calculated as the percentage change in leaf $\mathrm{N}$ or $\mathrm{P}$ per area from young (but fully expanded) green leaves to senesced leaves or fresh leaf litter. Leaf and litter collections were made several times for each species over a 2-3-year period, each collection representing the mean $\mathrm{N}$ or $\mathrm{P}$ concentration across several individuals. $\mathrm{N}$ and $\mathrm{P}$ resorption were known for 21 and 23 species, respectively.

\section{Testing for associations among traits and trait shifts}

Congruence among trends in leaf angle and light availability along age sequences was examined in two ways. First, species were grouped by the sign of their effective leaf angle or blade angle ANCOVA slopes (Table 1) and group differences in $\triangle$ absGF and $\Delta$ relGF tested for ( $t$-tests or ANOVA with a Tukey post-hoc test, as appropriate). Second, pairwise correlations (Pearson) were examined between GF decline and the size of mean species-shifts in leaf angle. Congruence among shifts in leaf angle and in other leaf traits along age sequences was also examined in two ways: first, by testing for congruence among the signs of ANCOVA slopes (Spearman rank correlation; ANCOVA signs coded as $-1,0$ or 1 ); second, by testing for differences in mean leaf angle shifts for species grouped by the sign of the ANCOVA slopes for the other leaf traits. Relationships between canopy shifts in leaf traits, light attenuation and other leaf and canopy properties were tested similarly: species were grouped by sign of the ANCOVA slopes and mean differences tested in $\triangle \mathrm{absGF}, \Delta$ relGF, LL, N and $\mathrm{P}$ resorption efficiency, LMA of the youngest leaf class $\left(\mathrm{LMA}_{1}\right)$, LAI and LMI (high rainfall species only). Finally, pairwise Pearson correlations were quantified among absGF, $\Delta$ relGF, $\mathrm{LMA}_{1}, \mathrm{LL}$, and $\mathrm{N}$ and $\mathrm{P}$ resorption. LAI and LMI were $\log _{10}$-transformed before analyses because both showed strongly right-skewed distributions among species; no other data required transformation.

\section{Results}

\section{Age-related trends in light availability and leaf traits in low rainfall species}

Species-mean decreases in light availability (GF) along leaf age sequences ranged from 18 to $48 \%$ (all $P<0.04$, except $P=0.103$ in one species; mean, $32 \%$; Table 1). LMA increased with leaf age in 9 of the 14 species (marginally so in one; Table 1, Fig. 2), the mean species shifts ranging from 10 to $38 \%$ (mean $20 \%$ ). $\mathrm{N}_{\text {mass }}$ decreased with leaf age in 10 species (by between 9 and 30\%, mean 17\%). Trends in LMA and $\mathrm{N}_{\text {mass }}$ tended to counteract one another, resulting in lower $\mathrm{N}_{\text {area }}$ in older leaves in three species (shifts from 11 to $18 \%$ ), and higher $\mathrm{N}_{\text {area }}$ in older leaves of four species, of which two were only marginally significant (shifts from 12 to $19 \%$ ). Still, even in these species it was apparent that $\mathrm{N}$ was resorbed before leaf fall $\left(\mathrm{N}_{\mathrm{area}}\right.$ of senescent leaves shown in Fig. 3). 

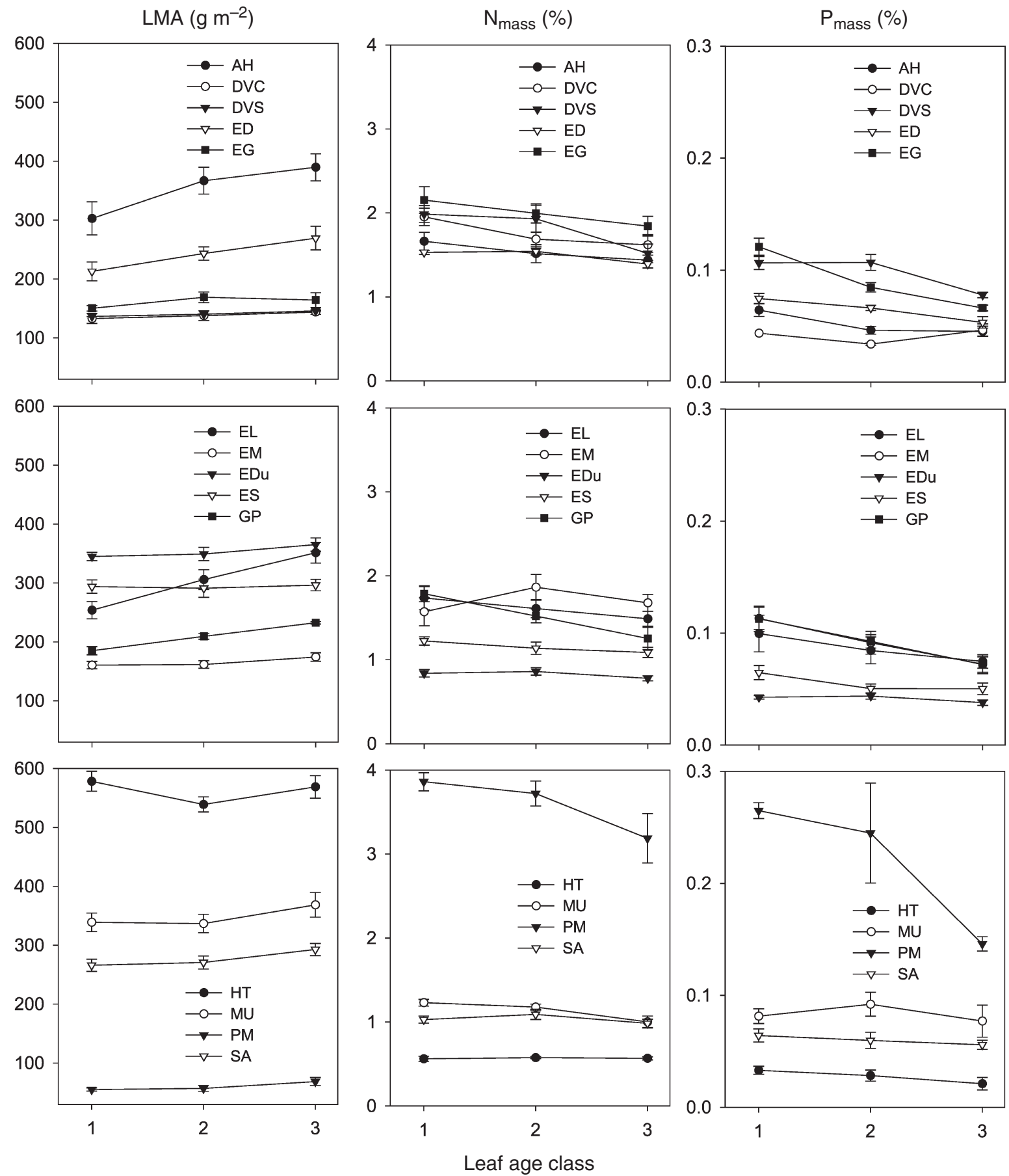

Fig. 2. Trends in LMA and leaf $\mathrm{N}$ and $\mathrm{P}$ concentration with leaf age for 14 shrub and tree species from low rainfall communities in eastern Australia. Species codes are given in the legend for Table 1. Leaf age sequences were divided into three equal length sections (positions $1-3$, position 1 being the youngest age class); for these the mean LMA, $\mathrm{N}_{\text {mass }}$ or $\mathrm{P}_{\text {mass }}( \pm 1$ s.e.) is shown ( $n=6$ except for DVC, for which $n=5$ ).

$\mathrm{P}_{\text {mass }}$ decreased along leaf age sequences in 9 of 14 species (one marginally; shifts from 25 to $45 \%$, mean $33 \%$; Table 1 , Fig. 2). Although the LMA and $P_{\text {mass }}$ trends would tend to counteract one another, the shifts in $P_{\text {mass }}$ were sufficiently strong that $\mathrm{P}_{\text {area }}$ decreased significantly in six species (one marginally; by $10-41 \%$, mean $24 \%$ ). Most species appeared to resorb leaf $\mathrm{P}$ before leaf fall (Fig. 3). In several species the stronger decrease in $P_{\text {mass }}$ than $\mathrm{N}_{\text {mass }}$ resulted in leaf $\mathrm{N}$ : $\mathrm{P}$ ratio increasing as leaves aged (Table 1 ). The most dramatic shift was seen in Hakea tephrosperma (Proteaceae), 

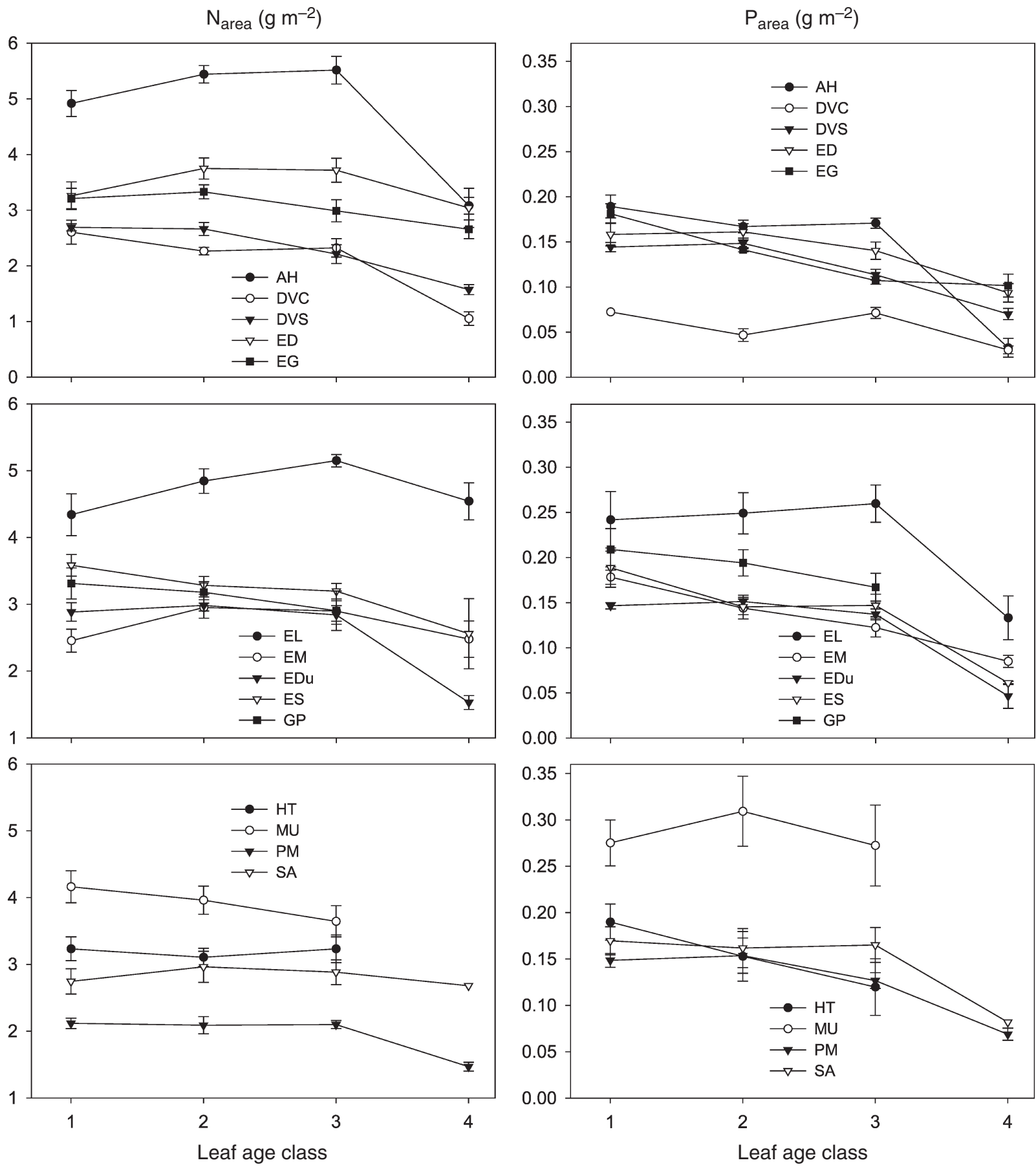

Fig. 3. Trends in leaf $\mathrm{N}$ and $\mathrm{P}$ per unit area with leaf age for 14 shrub and tree species from low rainfall communities in eastern Australia. Species codes are given in the legend for Table 1. Leaf age sequences were divided into three equal length sections (positions 1-3, position 1 being the youngest age class); for these the mean $\mathrm{N}_{\text {area }}$ or $\mathrm{P}_{\text {area }}( \pm 1$ s.e.) is shown $(n=6$ except for DVC, for which $n=5)$. Where known, $\mathrm{N}_{\text {area }}$ and $\mathrm{P}_{\text {area }}$ of senescent leaves or fresh leaf litter is shown as position 4 (data from Wright and Westoby 2003).

leaf $\mathrm{N}: \mathrm{P}$ ratio increasing from 17.9 to 40.5 ; the least dramatic in Eucalyptus socialis (Myrtaceae), increasing from 19.7 to 22.5 .

Midrib angle increased (became increasingly less vertical) along leaf age sequences in 7 of 14 species (one marginally) and decreased in one (Table 1). The seven positive species shifts averaged from $9^{\circ}$ to $64^{\circ}$. In two cases (Eremophila longifolia and, to a lesser extent, E. glabra; Myoporaceae) this trend continued past horizontal, with older leaves pointing increasingly downwards. Recoded to 'effective' leaf angle 
(see Materials and methods), five species showed increasingly steep leaf angles along sequences and three species showed the opposite trend (in each case one species was marginally significant). Considered this way E. longifolia now showed a negative rather than a positive trend in leaf angle: as leaves became increasingly pendulous with increasing age their effective angle was closer to vertical. Only four species showed any trend with leaf age when the effect of petiole twisting was taken into account ('blade' angle), light interception angles becoming less steep with leaf age in two species (positive fall angle trends), and more steep with age in two (one marginally; Table 1).

\section{Canopy trends in light availability and leaf traits in high rainfall species}

Light availability (GF) decreased back along leaf age sequences by between 20 and $61 \%$, depending on the species (mean 39\%; Table 2). This trend was significant in 13 of 14 species (though only marginally in Grevillea speciosa, $P=0.081$ ) and non-significant in one (Lambertia formosa, $P=0.133$ ). $\mathrm{N}_{\text {mass }}$ decreased along age sequences in 7 of 14 species (one marginally; mean shifts ranged from 10 to $26 \%$ ), i.e. somewhat less commonly than seen among the low rainfall species (10 of 14 species), but of similar magnitude, where significant.

Gap fraction declined vertically down through the canopy in all 14 species (all $P \ll 0.001$; Table 2), with species-mean shifts ranging from 20 to $62 \%$ (mean $41 \%$ ), an almost identical range to that seen along the age-sequences. LMA increased downwards in five species (two marginally), and decreased in two species (Table 2). The LMA shifts were only modest in size, positive shifts ranging from 6 to $13 \%$ and negative shifts from 3 to $12 \%$. $\mathrm{N}_{\text {mass }}$ decreased downwards in five species (of which two were marginally significant). On average, the magnitude of these shifts (ranging from 8 to $12 \%$ ) was about half of that along the age sequences measured on the same plants $(9.6 \%$ v. $18.7 \%)$. $\mathrm{N}_{\text {area }}$ showed a significant trend in two species only, decreasing down through the canopy in one by $16 \%$, and in the other by $19 \%$.

\section{Congruence among the canopy trends and with other plant traits}

\section{Low rainfall species}

Age-related trends in leaf angle were only weakly related to trends in light availability or in other leaf traits. The only significant trends were that species with more strongly increasing blade angle showed less absolute decline in GF (Pearson $r=-0.54, P=0.043$ ), as would be expected, and for a positive correlation between the sign of shifts in blade angle and N:P ratios (Spearman $r=0.54, P=0.046$ ). Species in which effective leaf angle increased with age had lower LMA in their younger leaves $\left(\mathrm{LMA}_{1}\right.$; compared to species showing no trend, $P=0.087$; to those with a negative trend, $P=0.039$; to all species with non-positive trends, $P=0.063$ ).

Species with positive LMA-leaf age relationships differed from those showing no LMA-age trend in that they had

Table 2. Summary of trait shifts along leaf age sequences and with distance down vertical canopy profiles of 14 shrub species from a high rainfall community in eastern Australia

Trait abbreviations as in Table 1. Species codes: AS, Acacia suaveolens; BS, Banksia spinulosa; BL, Boronia ledifolia; EA, Eriostemon australasius; GG, Gompholobium grandiflorum; GB, Grevillea buxifolia; GS, G. speciosa; HD, Hakea dactyloides; HT, H. teretifolia; HB, Hibbertia bracteata; LF, Lambertia formosa; LT, Leptospermum trinervium; PL, Persoonia levis; PP, Phyllota phylicoides. Trait shifts were identified with analyses of covariance. Leaf age sequences: declines in GF were clearly significant in 12 of 14 species (all $P<0.015)$, less so in GS $(P=0.081)$, and weaker again in LF $(P=0.133)$. The absolute and relative declines in GF are given below. Vertical profiles: declines in GF were clearly significant in all species (all $P<0.007$ ). For other traits the significance level is given, followed by the sign of the common slope where deemed significant, or marginally so $(0.05<P<0.10)$

\begin{tabular}{lcccccccc}
\hline & \multicolumn{3}{c}{ Leaf age sequences } & \multicolumn{4}{c}{ Vertical canopy profiles } \\
Species & $\Delta$ absGF & $\Delta$ relGF (\%) & $N_{\text {mass }}$ & $\Delta$ absGF & $\Delta$ relGF (\%) & LMA & $N_{\text {mass }}$ & $N_{\text {area }}$ \\
\hline AS & 0.14 & 31 & $0.004,-$ & 0.17 & 31 & $0.005,+$ & 0.148 & 0.797 \\
BS & 0.20 & 40 & $0.016,-$ & 0.14 & 27 & 0.919 & $0.048,-$ & 0.582 \\
BL & 0.14 & 30 & $0.038,-$ & 0.15 & 30 & $0.060,+$ & $0.028,-$ & 0.847 \\
EA & 0.11 & 20 & $<0.001,-$ & 0.11 & 20 & $0.051,+$ & $0.076,-$ & 0.260 \\
GG & 0.20 & 38 & 0.102 & 0.20 & 40 & 0.312 & 0.162 & 0.200 \\
GB & 0.22 & 51 & $0.003,-$ & 0.25 & 61 & $0.036,+$ & 0.229 & 0.257 \\
GS & 0.19 & 30 & 0.500 & 0.23 & 37 & 0.134 & 0.715 & 0.180 \\
HD & 0.36 & 61 & 0.380 & 0.33 & 62 & 0.397 & 0.775 & 0.465 \\
HT & 0.22 & 42 & 0.876 & 0.25 & 44 & 0.770 & 0.198 & 0.143 \\
HB & 0.15 & 42 & 0.481 & 0.16 & 43 & 0.244 & $0.084,-$ & $0.011,-$ \\
LF & 0.17 & 33 & $0.064,-$ & 0.19 & 34 & $0.020,-$ & 0.666 & 0.791 \\
LT & 0.26 & 48 & $0.004,-$ & 0.25 & 49 & $0.005,-$ & $0.001,-$ & $<0.001,-$ \\
PL & 0.16 & 36 & 0.286 & 0.34 & 59 & 0.727 & 0.278 & 0.435 \\
PP & 0.21 & 41 & 0.736 & 0.19 & 39 & $<0.001,+$ & 0.911 & 0.143 \\
\hline
\end{tabular}


lower $\mathrm{LMA}_{1}(P=0.028)$ and shorter LL $(P=0.079)$. Species with negative $\mathrm{N}_{\text {mass }}$-leaf age relationships differed from those showing no trend in that they had less light attenuation along leaf sequences ( $\triangle$ absGF, $P=0.032 ; \Delta$ relGF, $P=0.064$ ) in conjunction with lower $\mathrm{LMA}_{1}(P=0.085)$. Besides $\mathrm{LL}$ and $\mathrm{LMA}_{1}$ being positively correlated across species ( $r=0.76, P=0.002)$ there were no other relationships found between LL, LMA, GF decline or nutrient resorption efficiencies, nor other significant group differences in these traits.

\section{High rainfall species}

There were no mean differences in GF decline, LL or nutrient resorption efficiencies among species grouped by the sign of their $\mathrm{N}_{\text {mass }}-$ leaf age relationships ( $t$-tests, all $P>0.3)$. The only other significant relationship among traits measured on age sequences was a weak positive correlation between $\Delta$ absGF and $\% \mathrm{P}$ resorption $(r=0.56$, $P=0.061, n=12$ ).

Species in which LMA increased vertically down through the canopy had generally lower LAI $(P=0.045)$ and LMI $(P=0.065)$ than species with no LMA trend (or compared to all the species with non-positive trends, $P=0.012$ and 0.023 , respectively). Species that showed $\mathrm{N}_{\text {mass }}$ decreasing downwards tended to have less absolute light attenuation ( $\triangle$ absGF, $P=0.042$; but not $\Delta$ relGF, $P=0.113$ ), lower LAI and LMI (both $P=0.019)$ and shorter LL (1.3 v. 2.3 years; $P=0.055)$, but higher $\mathrm{N}$ resorption efficiency $(41 \%$ v. $26 \%$; $P=0.080) . \mathrm{N}_{\text {area }}$ also decreased downwards in two of these three species; thus they too had higher $\mathrm{N}$ resorption than species showing no $\mathrm{N}_{\text {area }}$ trend $(50 \%$ v. 27\%, $P=0.032)$. Species with longer LL and higher $\mathrm{LMA}_{1}$ accumulated more total leaf area or mass in their vertical profiles; in turn, LAI and LMI were tightly correlated with the degree of vertical light attenuation (Table 3). P resorption was weakly related to absolute light decline through canopy profiles, and to LL and LMI (Table 3).

\section{Discussion}

As expected, light availability (GF) generally declined along age sequences and down vertical canopy profiles, speciesmean shifts ranging from 18 to $62 \%$. However, the shifts in $\mathrm{N}_{\text {area }}$, LMA and leaf angle were only rarely in the direction predicted from optimisation models. LMA decreased with canopy depth in two species only; in fact it increased with leaf age / depth in 14 of 28 species. $N_{\text {area }}$ decreased in the expected direction in only 5 of 28 species. $P_{\text {area }}$ decreased with leaf age in approximately half of the 14 species for which it was measured. Effective leaf angle became less vertical with leaf age / canopy depth in approximately one third of species; however, due to twisting of petioles, the steepest angle across leafblades became less vertical with age / depth in two species only. In summary, trends in $\mathrm{P}_{\text {area }}$ were more consistent with optimisation predictions than trends in $\mathrm{N}_{\text {area }}$, trends in leaf angle accorded with predictions to various degrees, and shifts in LMA went quite strongly against predictions.

At first glance these results seem quite unusual. It is generally thought that most species show canopy trends in leaf traits consistent at least in direction with optimisation predictions and, given that leaves deeper in the canopy tend to be older, trends with leaf age should broadly mirror those with canopy depth (Anten 2005; Hikosaka 2005; Hirose 2005; Terashima et al. 2005). However, when studies focusing specifically on age-related changes in leaf traits are considered together, it seems that there are more exceptions than is usually recognised, particularly for trends in LMA.

Table 3. Correlations between absolute and relative light attenuation down vertical canopy profiles $(\Delta$ absGF, $\Delta$ relGF) and other leaf and canopy traits for the 14 high rainfall species (Table 2)

Abbreviations: $\mathrm{LMA}_{1}$, average LMA of uppermost leaf class; LL, average leaf lifespan; Nresorp, Presorp, \% $\mathrm{N}$ and $\mathrm{P}$ resorption from green to senescent leaves; LAI, total leaf area per ground area through profile; LMI, total leaf mass per ground area through profile. Significance levels

(in parentheses) follow correlation $r$-values, with sample sizes given beneath. Significant correlations $(\alpha=0.05)$ are indicated in bold type

\begin{tabular}{|c|c|c|c|c|c|c|c|}
\hline & $\Delta \mathrm{absGF}$ & $\Delta \mathrm{relGF}$ & $\mathrm{LMA}_{1}$ & LL & Nresorp & Presorp & LAI \\
\hline$\Delta \mathrm{relGF}$ & $\begin{array}{c}\mathbf{0 . 8 9} \\
14\end{array}(<0.001)$ & & & & & & \\
\hline $\mathrm{LMA}_{1}$ & $\begin{array}{l}0.40(0.161) \\
14\end{array}$ & $\begin{array}{l}0.15(0.606) \\
14\end{array}$ & & & & & \\
\hline LL & $\begin{array}{l}\mathbf{0 . 7 0}(0.007) \\
13\end{array}$ & $\begin{array}{l}0.46(0.113) \\
13\end{array}$ & $\begin{array}{l}\mathbf{0 . 5 7}(0.043) \\
13\end{array}$ & & & & \\
\hline Nresorp & $\begin{array}{l}0.10(0.772) \\
11\end{array}$ & $\begin{array}{l}0.11(0.744) \\
11\end{array}$ & $\begin{array}{l}-0.41(0.206) \\
\quad 11\end{array}$ & $\begin{array}{l}0.10(0.760) \\
11\end{array}$ & & & \\
\hline Presorp & $\begin{array}{l}\mathbf{0 . 6 1}(0.035) \\
12\end{array}$ & $\begin{array}{l}0.45(0.142) \\
12\end{array}$ & $\begin{array}{l}0.45(0.145) \\
12\end{array}$ & $\begin{array}{l}0.54(0.068) \\
12\end{array}$ & $\begin{array}{l}0.28(0.408) \\
11\end{array}$ & & \\
\hline LAI & $\begin{array}{c}\mathbf{0 . 8 5} \\
14\end{array}(<0.001)$ & $\begin{array}{l}\mathbf{0 . 6 9}(0.006) \\
14\end{array}$ & $\begin{array}{c}\mathbf{0 . 5 6}(0.038) \\
14\end{array}$ & $\begin{array}{l}\mathbf{0 . 7 6}(0.002) \\
13\end{array}$ & $\begin{array}{l}0.04(0.906) \\
11\end{array}$ & $\begin{array}{l}0.47(0.126) \\
12\end{array}$ & \\
\hline LMI & $\begin{array}{c}\mathbf{0 . 7 9} \\
14\end{array}$ & $\begin{array}{l}\mathbf{0 . 5 7} \\
14\end{array}$ & $\begin{array}{l}\mathbf{0 . 7 6}(0.002) \\
14\end{array}$ & $\begin{array}{l}\mathbf{0 . 8 1}(0.001) \\
13\end{array}$ & $\begin{array}{c}-0.09(0.783) \\
11\end{array}$ & $\begin{array}{l}0.51(0.088) \\
12\end{array}$ & $\begin{array}{l}0.96 \\
14\end{array}(<0.001)$ \\
\hline
\end{tabular}


For example, in several studies LMA has increased with leaf age in all or in the majority of species studied (as found here), showing no trend if not increasing (Ralhan and Singh 1987; Leuning et al. 1991; Schmid and Bazzaz 1994; Traw and Ackerly 1995; Kitajima et al. 1997; Anten et al. 1998; Valladares and Pearcy 1999; Escudero and Mediavilla 2003; Niinemets et al. 2004; Muraoka and Koizumi 2005; Niinemets et al. 2005). Increasing LMA with leaf age is most likely due to continual accumulation and lignification of cell wall materials (Mediavilla and Escudero 2003a; Niinemets et al. 2004), although direct evidence for this mechanism is scarce (Hom and Oechel 1983). Indirect evidence comes from increases in leaf $\mathrm{C}$ and/or $\mathrm{Ca}$ content with leaf age (Ralhan and Singh 1987; Niinemets et al. 2004), and decreases in mesophyll resistance (Niinemets et al. 2005) and photosynthetic capacity per unit leaf $\mathrm{N}$ (Escudero and Mediavilla 2003).

\section{Canopy trends in LMA tend to drive those in leaf nutrients}

There is growing evidence that canopy trends in LMA strongly influence trends in $\mathrm{N}_{\text {area }}$. For example, in several studies where LMA has decreased vertically downwards, this trend has driven $\mathrm{N}_{\text {area }}$ down also, $\mathrm{N}_{\text {mass }}$ being invariant with canopy depth (Hollinger 1989; Ellsworth and Reich 1993; Rambal et al. 1996; Anten et al. 1998; Niinemets et al. 1998, 2004; Carswell et al. 2000; Meir et al. 2002; Aranda et al. 2004). But shifts in LMA tend to drive those in $\mathrm{N}_{\text {mass }}$ also. In several studies where LMA has been found to increase with leaf age, this has had the effect of 'diluting' $\mathrm{N}_{\text {mass }}$, i.e. $\mathrm{N}_{\text {mass }}$ has decreased over time (Ralhan and Singh 1987; Kitajima et al. 1997; Valladares and Pearcy 1999; Mediavilla and Escudero 2003b). In some cases gradual $\mathrm{N}$ resorption has also contributed to the declining $\mathrm{N}_{\text {mass }}$, as evidenced by a concomitant trend of decreasing $\mathrm{N}_{\text {area }}$ (Traw and Ackerly 1995; Anten et al. 1998; Close et al. 2004; Niinemets et al. 2005).

Here, too, dilution from increasing LMA and nutrient resorption (i.e. decreasing $\mathrm{N}_{\text {area }}$ ) could be seen to determine the observed canopy trends in $\mathrm{N}_{\text {mass }}$. Down the vertical profiles (high rainfall only), along which $\mathrm{N}_{\text {mass }}$ decreased in 5 of 14 species, the trend was driven by LMA alone in two cases, by resorption alone in one, and by both, presumably (in one species it was unclear), in the other two species (Table 2). Along age sequences of low rainfall species the LMA effect tended to be stronger than the resorption effect, increases in LMA clearly driving the decreases in $\mathrm{N}_{\text {mass }}$ in 6 of the 10 species; conversely, resorption alone drove the $\mathrm{N}_{\text {mass }}$ decrease in two species only (Eucalyptus socialis and Melaleuca uncinata; Table 1). Interestingly, LMA dilution and nutrient resorption contributed more equally to decreases in $\mathrm{P}_{\text {mass }}$ with leaf age, with the trend driven by LMA alone in three cases, by resorption alone in two, and by both effects together in four species (Table 1). $\mathrm{P}_{\text {area }}$ decreased with leaf age in 6 of 14 species, indicating that $\mathrm{P}$ was being continually withdrawn from leaves over time (Fig. 3), whereas $\mathrm{N}_{\text {area }}$ decreased with age in three species only. The greater extent of $\mathrm{P}$ withdrawal was evident also in that $\mathrm{N}: \mathrm{P}$ ratios increased with leaf age in approximately half the species. Apparently this difference was maintained right through to leaf senescence; across the 14 low rainfall species mean $\mathrm{N}$ resorption was $28 \%$ but mean P resorption $56 \%$ (Wright and Westoby 2003), consistent with the expectation that higher relative energetic expenditure on $\mathrm{P}$ rather than $\mathrm{N}$ resorption may be advantageous when growing on low P soils (see 'Other possible reasons for deviations between observed and predicted canopy trends', below). We note that a higher level of $\mathrm{P}$ resorption than $\mathrm{N}$ resorption was also seen in the larger dataset from which these 14 species were drawn (73 species from four sites; Wright and Westoby 2003).

\section{Partial uncoupling of age-related trends in leaf $N$ and $P$}

How is it that time trends in leaf $\mathrm{N}$ and $\mathrm{P}$ were partially uncoupled? The largest pools of leaf $\mathrm{N}$ are photosynthetic proteins and pigments, whereas the majority of leaf $\mathrm{P}$ is found in nucleic acids and lipid membranes (Chapin and Kedrowski 1983; Sterner and Elser 2002). Thus it is also possible that, besides any differences in absolute requirements for resorbed $\mathrm{P} v$. resorbed $\mathrm{N}$, there could be different temporal requirements for redeployment of these nutrients to actively growing parts of the canopy. For example, there could be a relatively greater need for P-rich nucleic acids during leaf expansion and, after that, a relatively greater need for photosynthetic proteins. It is possible that differences in temporal requirements such as these could underlie the observed increases in $\mathrm{N}: \mathrm{P}$ ratios with leaf age. However, since age-related trends in both leaf $\mathrm{N}$ and $\mathrm{P}$ have been reported only rarely, it is unclear whether this is a general phenomenon or one peculiar to the species we studied. While similar age-related trends in leaf $\mathrm{P}$ and $\mathrm{N}$ have been observed in several tree species (Chapin and Kedrowski 1983; Nambiar and Fife 1991; Mediavilla and Escudero 2003a; Niinemets et al. 2004; Milla et al. 2005), in other species $\mathrm{N}$ and $\mathrm{P}$ have shown rather different time trends (Hevia et al. 1999).

\section{Do species from open habitats show weaker canopy trends in leaf traits?}

Having reconsidered the primary literature, the discrepancies between expectations from optimisation models and the canopy trends in LMA and $\mathrm{N}_{\text {area }}$ that we observed seem less unusual. Still, given that light availability generally decreases back along age sequences and down vertical canopy profiles, why would plants not be advantaged by creating a matching gradient in $\mathrm{N}_{\text {area }}$ ? One possibility, especially pertinent here, is that the photosynthetic benefit of a non-uniform $\mathrm{N}_{\text {area }}$ distribution may be sufficiently small 
as to be insignificant in open-canopied species (Mooney et al. 1981; Hirose and Werger 1987; Werger and Hirose 1991). However, even quite small increases in canopy photosynthesis have the potential to positively affect plant performance. In Lepechinia calycina (an open-canopied desert shrub), for example, observed canopy $\mathrm{N}_{\text {area }}$ gradients were estimated to increase photosynthesis by only $1 \%$ over a uniform distribution, but this was still considered significant (Field 1983). A similarly small photosynthetic benefit (from 1 to $5 \%$ ) was predicted to result from optimising LMA through the canopy of a model crop species (Gutschick and Wiegel 1988). Again, this seemingly small advantage was predicted to lead to a considerable competitive advantage over time, especially as the optimal LMA distribution would also maximise shading of any shorter, neighbouring plants.

Here, the age-related decreases of $11-18 \%$ in $\mathrm{N}_{\text {area }}$ were accompanied by decreases in GF of between 22 and $28 \%$; those in $\mathrm{P}_{\text {area }}$ ranged from 10 to $41 \%$ and were accompanied by $18-48 \%$ decreases in GF (Table 1). $\mathrm{N}_{\text {area }}$ decreased with vertical canopy depth by $16-19 \%$, accompanied by $42-48 \%$ decreases in GF (Table 2). Are shifts in leaf traits of this magnitude likely to be meaningful for canopy photosynthesis? Unfortunately we cannot answer that question: attempting to estimate the magnitude of any such advantage was beyond the scope of this study, requiring measurement of photosynthetic parameters in combination with detailed modelling of long-term carbon gain (Valladares and Pearcy 1999; Muraoka and Koizumi 2005). However, we were able to test whether species with more open canopies (with more shallow light gradients) were more likely to show canopy trends at odds with predictions from optimisation models. For LMA the proposition was supported: species in which LMA increased with leaf age or canopy depth had either lower LAI and LMI (high rainfall) or lower LMA and shorter LL (low rainfall) than other species. Across all species, as for evergreen species elsewhere (Reich et al. 1992; Gower et al. 1993; Warren and Adams 2000), longer LL was associated with higher LMI and LAI (more closed canopies), and with steeper light gradients. Because trends of increasing LMA largely drove the trends of decreasing $\mathrm{N}_{\text {mass }}$ (especially along age sequences), species with increasing LMA or with decreasing $\mathrm{N}_{\text {mass }}$ tended to have similar relationships with other traits. By contrast, the propensity for canopy trends in $\mathrm{N}_{\text {area }}$ (or $\mathrm{P}_{\text {area}}$ ) was unrelated to other measured traits, with the exception that species with vertically decreasing $\mathrm{N}_{\text {area }}$ tended to have higher $\mathrm{N}$ resorption efficiency, as might be expected.

\section{Other possible reasons for deviations between observed and predicted canopy trends}

Many additional reasons have been suggested for discrepancies between observed canopy trends and predictions from optimisation models (Anten 2002, 2005;
Givnish 2002; Kull 2002; Eichelmann et al. 2005; Hirose 2005). With respect to predictions concerning canopy gradients in $\mathrm{N}_{\text {area }}$, possible reasons include the fact that not all leaf $\mathrm{N}$ is related to photosynthesis (Hikosaka 2005), that there may be optimisation of $\mathrm{N}$ to light gradients within leaves as well as through canopies (Terashima et al. 2005), and that plants may 'over-invest' in Rubisco in order to cope with temporal vagaries in the environment (Warren et al. 2000). Another reason relates to what is actually being optimised in the models. Most commonly the object has been to identify trait optima for individual plants, or for monospecific stands. However, when density-dependent competitive effects from neighbouring species have been incorporated into models (making them 'game-theoretic'), the discrepancies between predictions and observations have tended to be smaller (Hikosaka and Hirose 1997; Schieving and Poorter 1999; Anten 2002, 2005).

Another set of possibilities concern the cost/benefit function in optimisation models that dictates when leaf $\mathrm{N}$ should begin to be resorbed from shaded leaves and redeployed to better lit parts of the canopy (i.e. when the photosynthetic benefits of $\mathrm{N}$ redistribution outweigh the costs involved). Although many processes can potentially contribute to the cost part of the function, few of these processes have been explicitly included in models to this point. Costs include those from constructing new leaves and their supporting structures and from replacing nutrients that are lost when senescent leaves are shed, including costs of root construction and energy required for nutrient uptake and assimilation (Field 1983; Ackerly 1999; Kikuzawa and Ackerly 1999; Franklin and Agren 2002; Givnish 2002). Furthermore, the cost of nutrient uptake varies according to the form in which they are available in soil, e.g. whether $\mathrm{N}$ is available as nitrate, ammonium or amino acids (Gutschick 1981), what concentration the different pools are present in, and whether maintaining symbiotic relationships is necessary for uptake (e.g. mycorrhizae or $\mathrm{N}_{2}$-fixing bacteria). Plants have the option of obtaining nutrients required for new leaves from either the soil or via resorption from old leaves (Wright and Westoby 2003). Presumably the relative cost of these different sources can vary for different nutrients, depending on their availability in the soil. That is, the relative cost of resorbed $\mathrm{P}$ to soil-derived $\mathrm{P}$ may be lower for plants growing in low $\mathrm{P}$ soils than the relative cost of resorbed $\mathrm{N}$ to soil-derived $\mathrm{N}$, with the opposite situation being the case for plants growing in soils where $\mathrm{N}$ is more limiting (Wright and Westoby 2003). As far as we aware, canopy optimisation models that have considered nutrients have only considered leaf $\mathrm{N}$, yet one of the most intriguing results from the current study was that leaf $\mathrm{P}$ showed considerably stronger 'optimisation' behaviour than did leaf N. This suggests that a further promising way forward might be to consider nutrients in addition to $\mathrm{N}$ in future optimisation models. 


\section{Conclusions}

In this study trends in light availability and in leaf structure, nutrient content and orientation were quantified through the canopies of 28 shrub and tree species from relatively open habitats in eastern Australia. This represents the largest interspecific quantification of canopy trends yet published and is one of only a handful of studies to consider Australian species. The observed trends were largely in conflict with expectations derived from canopy optimisation models. Most likely this reflected the fact that these species grow in high-light habitats and have rather open canopies (and thus quite shallow light gradients). Our results add to the growing evidence that there is greater variability in canopy organisation among plants than had been recognised previously, and that many species do not conform well to predictions from canopy optimisation models. Understanding age- and light-related variation in leaf and canopy properties is necessary for modelling the carbonnutrient budgets of plants and for gaining insight into the evolutionary pressures leading to differences among species adapted to different types of habitats (Small 1972; Aerts and Chapin 2000; Escudero and Mediavilla 2003). At the same time, there are limitations to attempting to understand plant canopies purely in terms of the maximisation of photosynthesis via leaf $\mathrm{N}$. In particular, we suggest that leaf $\mathrm{P}$ may be particularly important in the Australian context, but also that water use could usefully be considered simultaneously with carbon gain, especially in seasonally dry environments (Warren et al. 2000; Farquhar et al. 2002; Givnish 2002).

\section{Acknowledgments}

Wright, Westoby and Leishman acknowledge support for their research from the Australian Research Council, in part through the ARC-NZ Research Network for Vegetation Function. Additional funding also came from a Macquarie University Research Grant to Leishman and Wright. We are also greatly indebted to David Duncan, Angela Moles, Barbara Rice and Peter Vesk for their enthusiastic assistance in the field, and to two anonymous reviewers for their helpful comments on the manuscript.

\section{References}

Ackerly DD (1992) Light, leaf age, and leaf nitrogen concentration in a tropical vine. Oecologia 89, 596-600.

Ackerly DD (1999) Self-shading, carbon gain and leaf dynamics: a test of alternative optimality models. Oecologia 119, 300-310. doi: $10.1007 / \mathrm{s} 004420050790$

Aerts R, Chapin FS (2000) The mineral nutrition of wild plants revisited: a re-evaluation of processes and patterns. Advances in Ecological Research 30, 1-67.

Anten NPR (2002) Evolutionarily stable leaf area production in plant populations. Journal of Theoretical Biology 217, 15-32. doi: $10.1006 /$ jtbi.2002.3022
Anten NPR (2005) Optimal photosynthetic characteristics of individual plants in vegetation stands and implications for species coexistence. Annals of Botany 95, 495-506. doi: 10.1093/aob/mci048

Anten NPR, Miyazawa K, Hikosaka K, Nagashima H, Hirose T (1998) Leaf nitrogen distribution in relation to leaf age and photon flux density in dominant and subordinate plants in dense stands of a dicotyledonous herb. Oecologia 113, 314-324. doi: $10.1007 / \mathrm{s} 004420050382$

Anten NPR, Schieving F, Werger MJA (1995) Patterns of light and nitrogen distribution in relation to whole canopy carbon gain in $\mathrm{C}_{3}$ and $\mathrm{C}_{4}$ mono- and dicotyledonous species. Oecologia 101, 504-513. doi: 10.1007/BF00329431

Aranda I, Pardo F, Gil L, Pardos JA (2004) Anatomical basis of the change in leaf mass per area and nitrogen investment with relative irradiance within the canopy of eight temperate tree species. Acta Oecologica 25, 187-194. doi: 10.1016/j.actao.2004.01.003

Beadle NCW (1966) Soil phosphate and its role in molding segments of the Australian flora and vegetation, with special reference to xeromorphy and scleromorphy. Ecology 47, 992-1007.

Carswell FE, Meir P, Wandelli EV, Bonates LCM, Kruijt B, Barbosa EM, Nobre AD, Grace J, Jarvis PG (2000) Photosynthetic capacity in a central Amazonian rain forest. Tree Physiology 20, 179-186.

Chapin FS, Kedrowski RA (1983) Seasonal changes in nitrogen and phosphorus fractions and autumn retranslocation in evergreen and deciduous Taiga trees. Ecology 64, 376-391.

Close DC, Battaglia M, Davidson NJ, Beadle CL (2004) Withincanopy gradients of nitrogen and photosynthetic activity of Eucalyptus nitens and Eucalyptus globulus in response to nitrogen nutrition. Australian Journal of Botany 52, 133-140. doi: 10.1071/BT03027

Comeau PG, Gendron F, Letchford T (1998) A comparison of several methods for estimating light under a paper birch mixedwood stand. Canadian Journal of Forest Research 28, 1843-1850. doi: 10.1139/cjfr-28-12-1843

Eichelmann H, Oja V, Rasulov B, Padu E, Bichele I, Pettai H, Mand P, Kull O, Laisk A (2005) Adjustment of leaf photosynthesis to shade in a natural canopy: reallocation of nitrogen. Plant, Cell \& Environment 28, 389-401. doi: 10.1111/j.1365-3040. 2004.01275.x

Ellsworth DS, Reich PB (1993) Canopy structure and vertical patterns of photosynthesis and related leaf traits in a deciduous forest. Oecologia 96, 169-178. doi: 10.1007/BF00317729

Escudero A, Mediavilla S (2003) Decline in photosynthetic nitrogen use efficiency with leaf age and nitrogen resorption as determinants of leaf life span. Journal of Ecology 91, 880-889. doi: 10.1046/j.13652745.2003.00818.x

Falster DS, Westoby M (2003) Leaf size and angle vary widely across species: what consequences for light interception? New Phytologist 158, 509-525. doi: 10.1046/j.1469-8137.2003.00765.x

Farquhar GD, Buckley TN, Miller JM (2002) Optimal stomatal control in relation to leaf area and nitrogen content. Silva Fennica 36, 625-637.

Field C (1983) Allocating leaf nitrogen for the maximization of carbon gain: leaf age as a control on the allocation program. Oecologia 56, 341-347. doi: 10.1007/BF00379710

Franklin O, Agren GI (2002) Leaf senescence and resorption as mechanisms of maximizing photosynthetic production during canopy development at $\mathrm{N}$ limitation. Functional Ecology 16, 727-733. doi: 10.1046/j.1365-2435.2002.00674.x

Givnish TJ (1982) Adaptive significance of leaf height in forest herbs. American Naturalist 120, 353-381. doi: 10.1086/283995

Givnish TJ (2002) Adaptive significance of evergreen vs. deciduous leaves: solving the triple paradox. Silva Fennica 36, 703-743. 
Gower ST, Reich PB, Son Y (1993) Canopy dynamics and aboveground production of five tree species with different leaf longevities. Tree Physiology 12, 327-345.

Gutschick VP (1981) Evolved strategies in nitrogen acquisition by plants. American Naturalist 118, 607-637. doi: 10.1086/283858

Gutschick VP, Wiegel FW (1988) Optimizing the canopy photosynthetic rate by patterns of investment in specific leaf mass. American Naturalist 132, 67-86. doi: 10.1086/284838

Hevia F, Minoletti ML, Decker KLM, Boerner REJ (1999) Foliar nitrogen and phosphorus dynamics of three Chilean Nothofagus (Fagaceae) species in relation to leaf lifespan. American Journal of Botany 86, 447-455.

Hikosaka K (1996) Effects of leaf age, nitrogen nutrition and photon flux density on the organization of the photosynthetic apparatus in leaves of a vine (Ipomoea tricolor Cav.) grown horizontally to avoid mutual shading of leaves. Planta 198, 144-150. doi: 10.1007/BF00197597

Hikosaka K (2003) A model of dynamics of leaves and nitrogen in a canopy: an integration of canopy photosynthesis, leaf life-span, and nitrogen use efficiency. American Naturalist 162, 149-164. doi: $10.1086 / 376576$

Hikosaka K (2005) Leaf canopy as a dynamic system: ecophysiology and optimality in leaf turnover. Annals of Botany 95, 521-533. doi: $10.1093 / \mathrm{aob} / \mathrm{mci} 050$

Hikosaka K, Hirose T (1997) Leaf angle as a strategy for light competition - optimal and evolutionarily stable light-extinction coefficient within a leaf canopy. Ecoscience 4, 501-507.

Hirose T (2005) Development of the Monsi-Saeki theory on canopy structure and function. Annals of Botany 95, 483-494. doi: $10.1093 / \mathrm{aob} / \mathrm{mci} 047$

Hirose T, Werger MJA (1987) Maximizing daily canopy photosynthesis with respect to the leaf nitrogen allocation pattern in the canopy. Oecologia 72, 520-526. doi: 10.1007/BF00378977

Hollinger DY (1989) Canopy organization and foliage photosynthetic capacity in a broad-leaved evergreen montane forest. Functional Ecology 3, 53-62.

Hom JL, Oechel WC (1983) The photosynthetic capacity nutrient content and nutrient use efficiency of different needle age classes of black spruce (Picea mariana) found in interior Alaska, USA. Canadian Journal of Forest Research 13, 834-839.

Kikuzawa K, Ackerly D (1999) Significance of leaf longevity in plants. Plant Species Biology 14, 39-45. doi: 10.1046/j.14421984.1999.00005.x

Kitajima K, Mulkey SS, Wright SJ (1997) Decline of photosynthetic capacity with leaf age in relation to leaf longevities for five tropical canopy tree species. American Journal of Botany 84, 702-708.

Kull O (2002) Acclimation of photosynthesis in canopies: models and limitations. Oecologia 133, 267-279. doi: 10.1007/s00442-0021042-1

Kuroiwa S (1971) Total photosynthesis of a foliage in relation to inclination of leaves. In 'Prediction and measurement of photosynthetic productivity’. (Ed. I Šetlík) pp. 79-89. (Pudoc: Wageningen)

Leuning R, Cromer RN, Rance S (1991) Spatial distributions of foliar nitrogen and phosphorus in crowns of Eucalyptus grandis. Oecologia 88, 504-510.

Machado JL, Reich PB (1999) Evaluation of several measures of canopy openness as predictors of photosynthetic photon flux density in deeply shaded conifer-dominated forest understory. Canadian Journal of Forest Research 29, 1438-1444. doi: $10.1139 /$ cjfr-29-9-1438

Mediavilla S, Escudero A (2003a) Leaf life span differs from retention time of biomass and nutrients in the crowns of evergreen species. Functional Ecology 17, 541-548. doi: 10.1046/j.13652435.2003.00766.x
Mediavilla S, Escudero A (2003b) Photosynthetic capacity, integrated over the lifetime of a leaf, is predicted to be independent of leaf longevity in some tree species. New Phytologist 159, 203-211. doi: 10.1046/j.1469-8137.2003.00798.x

Meir P, Kruijt B, Broadmeadow M, Barbosa E, Kull O, Carswell F, Nobre A, Jarvis PG (2002) Acclimation of photosynthetic capacity to irradiance in tree canopies in relation to leaf nitrogen concentration and leaf mass per unit area. Plant, Cell \& Environment 25, 343-357. doi: 10.1046/j.0016-8025. 2001.00811.x

Milla R, Castro-Diez P, Maestro-Martinez M, Montserrat-Marti G (2005) Relationships between phenology and the remobilization of nitrogen, phosphorus and potassium in branches of eight Mediterranean evergreens. New Phytologist 168, 167-178. doi: $10.1111 / \mathrm{j} .1469-8137.2005 .01477 . x$

Monsi M, Saeki T (1953) Über den Lichtfaktor in den Pflanzengesellschaften und seine Bedeutung für die Stoffproduktion. Japanese Journal of Botany 14, 22-52.

Mooney HA, Field C, Gulmon SL, Bazzaz FA (1981) Photosynthetic capacity in relation to leaf position in desert versus old-field annuals. Oecologia 50, 109-112. doi: 10.1007/BF00378802

Mooney HA, Gulmon SL (1979) Environmental and evolutionary constraints on the photosynthetic characteristics of higher plants. In 'Topics in plant population biology'. (Eds OT Solbrig, S Jain, GB Johnson, PR Raven) pp. 316-337. (Columbia University Press: New York)

Muraoka H, Koizumi H (2005) Photosynthetic and structural characteristics of canopy and shrub trees in a cool-temperate deciduous broadleaved forest: implication to the ecosystem carbon gain. Agricultural and Forest Meteorology 134, 39-59. doi: 10.1016/j.agrformet.2005.08.013

Nambiar EK, Fife DN (1991) Nutrient retranslocation in temperate conifers. Tree Physiology 9, 185-207.

Niinemets Ü, Cescatti A, Rodeghiero M, Tosens T (2005) Leaf internal diffusion conductance limits photosynthesis more strongly in older leaves of Mediterranean evergreen broad-leaved species. Plant, Cell \& Environment 28, 1552-1566. doi: 10.1111/j.13653040.2005.01392.x

Niinemets Ü, Kull O, Tenhunen JD (1998) An analysis of light effects on foliar morphology, physiology, and light interception in temperate deciduous woody species of contrasting shade tolerance. Tree Physiology 18, 681-696.

Niinemets Ü, Tenhunen JD, Beyschlag W (2004) Spatial and age-dependent modifications of photosynthetic capacity in four Mediterranean oak species. Functional Plant Biology 31, 1179-1193. doi: 10.1071/FP04128

Ralhan PK, Singh SP (1987) Dynamics of nutrients and leaf mass in Central Himalayan forest trees and shrubs. Ecology 68, 1974-1983.

Rambal S, Damesin C, Joffre R, Methy M, Lo Seen D (1996) Optimization of carbon gain in canopies of Mediterranean evergreen oaks. Annales Des Sciences Forestieres 53, 547-560.

Read C, Wright IJ, Westoby M (2006) Scaling up from leaf to canopyaggregate properties in sclerophyll shrub species. Austral Ecology 31, (In press).

Reich PB, Walters MB, Ellsworth DS (1992) Leaf life-span in relation to leaf, plant, and stand characteristics among diverse ecosystems. Ecological Monographs 62, 365-392.

Schieving F, Poorter H (1999) Carbon gain in a multispecies canopy: the role of specific leaf area and photosynthetic nitrogen-use efficiency in the tragedy of the commons. New Phytologist 143, 201-211. doi: 10.1046/j.1469-8137.1999.00431.x

Schmid B, Bazzaz FA (1994) Crown construction, leaf dynamics, and carbon gain in two perennials with contrasting architecture. Ecological Monographs 64, 177-203. 
Small E (1972) Photosynthetic rates in relation to nitrogen cycling as an adaptation to nutrient deficiency in peat bog plants. Canadian Journal of Botany 50, 2227-2233.

Sterner RW, Elser JJ (2002) 'Ecological stoichiometry. The biology of elements from molecules to the biosphere.' (Princeton University Press: Princeton Oxford)

Terashima I, Araya T, Miyazawa S, Sone K, Yano S (2005) Construction and maintenance of the optimal photosynthetic systems of the leaf, herbaceous plant and tree: an eco-developmental treatise. Annals of Botany 95, 507-519. doi: 10.1093/aob/mci049

Traw MB, Ackerly DD (1995) Leaf position, light levels, and nitrogen allocation in five species of rain forest pioneer trees. American Journal of Botany 82, 1137-1143.

Valladares F, Pearcy RW (1999) The geometry of light interception by shoots of Heteromeles arbutifolia morphological and physiological consequences for individual leaves. Oecologia 121, 171-182. doi: $10.1007 / \mathrm{s} 004420050919$

Valladares F, Pugnaire FI (1999) Tradeoffs between irradiance capture and avoidance in semi-arid environments assessed with a crown architecture model. Annals of Botany 83, 459-469. doi: 10.1006/anbo.1998.0843

Warren CR, Adams MA (2000) Trade-offs between the persistence of foliage and productivity in two Pinus species. Oecologia 124, 487-494.

Warren CR, Adams MA, Chen ZL (2000) Is photosynthesis related to concentrations of nitrogen and Rubisco in leaves of Australian native plants? Australian Journal of Plant Physiology 27, 407-416. doi: 10.1071/PP98162
Webb LJ (1968) Environment relationships of the structural types of Australian rain forest vegetation. Ecology 49, 296-311.

Werger MJA, Hirose T (1991) Leaf nitrogen distribution and whole canopy photosynthetic carbon gain in herbaceous stands. Vegetatio 97, 11-20.

Werner C, Ryel RJ, Correia O, Beyschlag W (2001) Structural and functional variability within the canopy and its relevance for carbon gain and stress avoidance. Acta Oecologica 22, 129-138. doi: 10.1016/S1146-609X(01)01106-7

Wright IJ, Reich PB, Westoby M (2001) Strategy shifts in leaf physiology, structure and nutrient content between species of high and low rainfall, and high and low nutrient habitats. Functional Ecology 15, 423-434. doi: 10.1046/j.0269-8463.2001.00542.x

Wright IJ, Westoby M (2002) Leaves at low versus high rainfall: coordination of structure, lifespan and physiology. New Phytologist 155, 403-416. doi: 10.1046/j.1469-8137.2002.00479.x

Wright IJ, Westoby M (2003) Nutrient concentration, resorption and lifespan: leaf traits of Australian sclerophyll species. Functional Ecology 17, 10-19. doi: 10.1046/j.1365-2435.2003.00694.x

Wright IJ, Westoby M, Reich PB (2002) Convergence towards higher leaf mass per area in dry and nutrient-poor habitats has different consequences for leaf lifespan. Journal of Ecology 90, 534-543. doi: $10.1046 / j .1365-2745.2002 .00689 . x$

Manuscript received 31 December 2005, accepted 9 February 2006 